Pregledni naučni rad

Primljeno: 25. 1. 2017.

UDK: $341.48: 343.431$

Revidirana verzija: 27. 2. 2017.

Prihvaćeno: 1. 2. 2017.

doi: $10.5937 /$ nabepo21-12283

\title{
EUROPEAN AND INTERNATIONAL STANDARDS IN THE FIELD OF HUMAN TRAFFICKING
}

\author{
Anna Lucia Valvo \\ The Kore University of Enna, Sicily, Italy
}

Summary: Trafficking in human beings is a phenomenon which from time immemorial the international community has had to face through the arrangement of legal instruments for its prevention and suppression. The first international Conventions that faced the problem date back to the early 1900s although, at the time, trafficking in human beings was better known as "white slave trade" and concerned a phenomenon smaller than today. In fact, today's trafficking in human beings has boundaries wider than in the past, not only in terms of quantity but also in terms of quality of the organized criminal groups who are engaged in human trafficking. Qualified as a crime against humanity by the Rome Statute of July 1998 establishing the International Criminal Court, which in its Art. 7 includes enslavement as a crime against humanity prohibited by the Universal Declaration of Human Rights of December 10, 1948, today trafficking in human beings is also expressly prohibited by the Charter of Fundamental Rights of the European Union which in its Art. 5 provides that "no one shall be held in slavery or servitude; no one shall be required to perform forced or compulsory labour; trafficking in human beings is prohibited".

Keywords: trafficking of human beings, clandestine immigration, international law, the Warsaw Convention. 


\section{Introduction}

Trafficking in human beings is a phenomenon which from time immemorial the international community has had to face through the arrangement of legal instruments for its prevention and suppression. ${ }^{1}$

The first international Conventions ${ }^{2}$ that faced the problem date back to the early 1900s although, at the time, trafficking in human beings was better known as "white slave trade" and concerned a phenomenon smaller than today. In fact, today's trafficking in human beings has boundaries wider than in the past, not only in terms of quantity but also in terms of quality of the organized criminal groups who are engaged in human trafficking.

Qualified as a crime against humanity by the Rome Statute of July 1998 establishing the International Criminal Court, which in its Art. 7 includes enslavement as a crime against humanity, ${ }^{3}$ and prohibited by the Universal Declaration of Human Rights of December 10, 1948, ${ }^{4}$ today trafficking in human beings is also expressly prohibited by the Charter of Fundamental Rights of the European Union which in its Art. 5 provides that "no one shall be held in slavery or servitude; no one shall be required to perform forced or compulsory labour; trafficking in human beings is prohibited".

Unlike the past, today the crime of trafficking does not only consist of the exploitation of women forced into prostitution, but it affects a number of persons exploited in the labour market, and it also includes minors forced into begging and theft.

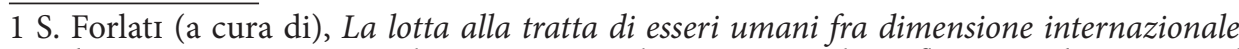
e ordinamento interno, Napoli, 2013; Nascimbene-Di Pascale, Riflessioni sul contrasto al traffico di persone nel diritto internazionale, comunitario e nazionale, in G. Palmisano (a cura di), Il contrasto al traffico di migranti nel diritto internazionale, comunitario e interno, Milano, 2008, p. 27 ss.

2 See, as an example, the "International Agreement for the suppression of the White Slave Traffic" of May 18, 1904. Ratified by Italy on January 18, 1905, the execution order had been given with the R. D. No. 171, April 9, 1905; the "International Convention for the Suppression of the White Slave" signed in Paris on May 4, 1910 and entered into force on February 8, 1913; the "International Convention for the Suppression of the Traffic in Women and Children", signed in Geneva on September 30, 1921, entered into force on June 18, 1922, which took into account even the male children; the "International Convention for the Suppression of the Traffic in Adult Women", signed in Geneva on October 11, 1933, entered into force August 24, 1934; the "International Convention for the Suppression of Trafficking in Human Beings and the Exploitation of the Prostitution of Others", of December 2, 1949, entered into force on July 25, 1951, etc.

3 Art. 7, paragraph 2, let. c) "'Enslavement' means the exercise of any or all of the powers attaching to the right of ownership over a person and includes the exercise of such power in the course of trafficking in persons, in particular women and children".

4 Art. 4: "No one shall be held in slavery or servitude; slavery and the slave trade shall be prohibited in all their forms". 
Trafficking in persons means serious crime that involves recruiting, transporting and subsequent exploiting of human beings for profit. Victims of trafficking are, for the greater part, people escaping from underdevelopment, poverty and social need in general, or women and children abducted or circumvented with promises of work or even people fleeing scenarios of violence and war.

A key feature of trafficking in persons, in addition to the violent or recruitment through deception, is the transfer of a victim across multiple countries and the sales of an individual from group to group before reaching the destination.

And because of this, trafficking in persons is a crime which is necessarily transnational in nature and, as we will see, the latter is an essential prerequisite specifically provided by the Palermo Protocol to prevent, suppress and punish trafficking in persons, especially women and children, the Additional Protocol to the UN Convention against transnational organised crime. ${ }^{5}$

The phenomenon of trafficking is often, although not necessarily, connected with smuggling of immigrants, from which, however, from a regulatory perspective, it is specifically distinct.

\section{Trafficking in human beings and clandestine immigration}

The United Nations Convention against Transnational Organized Crime is supplemented by three additional protocols: 1 . The Protocol to Prevent, Suppress and Punish Trafficking in Persons, Especially Women and Children, 2. The Protocol against the Smuggling of Migrants by Land, Sea and Air, and 3. The Protocol against the Illicit Manufacturing and Trafficking in Firearms, Their Parts and Components and Ammunition.

The Convention, therefore, makes a specific distinction between trafficking in human beings and the illegal transport of migrants (Smuggling of migrants).

The central elements of the crime of trafficking defined in the Protocol are coercion, abuse and deceit, the elements that are not necessarily present in the crime of illegal transport of migrants.

While human trafficking is essentially the forcible transfer for the purpose of exploitation (sexual or otherwise), smuggling of migrants is the illegal crossing of borders with the consent of the people who are helped to illegally cross the borders of the States.

In contrast with trafficking in human beings, a crime that involves the coercion of the victim, smuggling requires the consensus among the smuggler and

5 Adopted by the General Assembly in Resolution 55/25 of 15 November 2000 and signed in Palermo in December of that year. Adopted by the General Assembly in Resolution $55 / 25$ of 15 November 2000 and signed in Palermo in December of that year. 
the smuggled. The smuggling of migrants, moreover, does not imply the purpose of exploitation which is instead an essential element of trafficking and involves, in contrast to the crime of human trafficking, the violation of the rules on legal migration, a violation that in the crime of trafficking is only potential.

Under this specific profile it can also be argued that while smuggling is a crime against the state and has a transnational nature, trafficking is a crime against the person and it does not necessarily have a transnational nature. ${ }^{6}$

Although in the factual reality the distinction between the two offenses is not always clear as in its theoretical delineation, it can be said that the element that characterizes trafficking is the use of forced labour of the trafficked person rather than the issues related to the regular or irregular entry of the individual across the borders. ${ }^{7}$

Nevertheless, with regard to the element of movement a clear distinction is made in the Convention between trafficking in human beings and smuggling of migrants. As for the smuggling of migrants, its purpose is, as mentioned before, the illegal border crossings; smuggling of migrants mainly concerns the protection of States against irregular migration. ${ }^{8}$

The crime connected to the smuggling of migrants as such does not violate the rights and freedoms of the human person, but it causes a prejudice to the political interest of the States whose borders are irregularly validated.

"Illegal smuggling of migrants" in the dedicated Protocol (Art. 3, letter a.) means "the procurement, in order to obtain, directly or indirectly, a financial or other material benefit, of the illegal entry of a person into a State Party of which the person is not a national or a permanent resident".

The offence of smuggling of migrants is therefore comparable to the offence of assisting illegal immigration.

The constitutive elements and the conducts that fall under this offense are different. The main features of this hypothesis are:

a. the commission of the offense by an organized and structured criminal group;

b. the purpose of obtaining a financial gain or a benefit of another nature from the offense.

6 Cfr. Carella, La tratta degli esseri umani, in AA. Vv., L'immigrazione e la mobilità delle persone nel diritto dell'Unione europea, Milano, 2012, p. 207 ss; Amalfitano, Unione europea e tutela delle vittime della tratta di esseri umani, in G. Caggiano (a cura di), I percorsi giuridici per l'integrazione. Migranti e titolari di protezione internazionale tra diritto dell'Unione e ordinamento italiano, Torino, 2014, p. 755.

7 Cfr., in proposito, Obokata, EU Council Framework Decision on Combating Trafficking in Human Beings: a Critical Appraisal, in Common Market Law Review, 2003, p. 917 ss. 8 Gallagher, The international law of human trafficking, Cambridge University Press, New York, 2010. 
Considering the trafficking in human beings, as will be discussed below, its essential purpose is the exploitation of the trafficked person; the trafficking, therefore, presupposes the existence of a victim whose individual rights have been violated and the interest of the international community is essentially the specific protection of the person from the phenomena of exploitation and abuse. ${ }^{9}$

However, it is not always clear whether a person is trafficked or just clandestine. In conclusion to this point, we can say that, while both refer to a matrix of organized crime and there is possible overlapping and interweaving between the two crimes, the smuggling of migrants differs from the trafficking mainly for the consensual element that prevails on the coercive one, as well as for the duration of the relationship between the criminal organizations and the victims: generally, in the case of smuggling the relationship is interrupted once they arrive in the destination country, while in trafficking the exploitation of victims continues over time. ${ }^{10}$

\section{International law on trafficking in human beings}

The Palermo Protocol ${ }^{11}$ supplementing the above-mentioned United Nations Convention, which has as a specific objective the prevention and combating trafficking, the protection of victims and the promotion of the cooperation among States, it can be considered the point of reference of other regional regulatory instruments in the field of human trafficking.

In the wake of the aforementioned Palermo Protocol, in 2005 the Council of Europe in fact adopted the Convention on the action against trafficking in human beings. Subsequently, in the EU judicial system the Directive 2011/36/ EU (replacing the Council Framework Decision 2002/629/JHA) was enacted: both acts are based on the definitions of the Protocol (although with some applicative differences). ${ }^{12}$

\footnotetext{
9 Trafficking in human beings has been defined by the European Court of Human Rights as a "modern form of slavery"; see judgment of 7 January 2010 (application no. 25965/04) Rantsev c. Cipro e Russia.

10 Middlburg-Rijken, The EU Legal Framework on Combating Trafficking in Human Beings for Labour Exploitation, in C. Rijken (ed.), Combating Trafficking in Human Beings for Exploitation, Nijmegen, The Netherlands, Wolf Legal Publishers WLP, 2011.

11 The Additional Protocol to the United Nations Convention against Transnational Organized Crime to Prevent, Suppress and Punish Trafficking in Persons, especially Women and Children. Adopted by the General Assembly Resolution A/RES/55/25 of 15 November 2000. Entered into force on December 25, 2003. The Italian law authorizing the ratification is the no. 146 of March 16, 2006 (Official Journal no. 85 of April 11, 2006). Date of deposit of the instrument of ratification: August 2, 2006. Entry into force in Italy: September 1, 2006.

12 See, in this regard, Gabrielli, La Direttiva sulla tratta di esseri umani tra cooperazione giudiziaria penale, contrasto dell'immigrazione illegale e tutela dei diritti, in Studi sull'in-
} 
The Palermo Protocol, in its Art. 3, letter a) provides a clear definition of trafficking in persons. The elements that characterize the smuggling are:

1. the recruitment, transportation, transfer, harbouring, or receipt of persons;

2. by means of the threat or use of force or other forms of coercion, of abduction, of fraud, of deception, of the abuse of power or of a position of vulnerability or of the giving or receiving of payments or benefits to achieve the consent of a person having control over another person, for the purpose of exploitation;

3. for the purpose of exploitation of the prostitution of others or other forms of sexual exploitation, forced labour or services, slavery or practices similar to slavery, servitude or removal of organs.

Art. 3, letter b) provides that the consent of a victim of trafficking is irrelevant, while letter c), provides that the recruitment, transportation, transfer, harbouring or receipt of a child for the purpose of exploitation shall be considered "trafficking in persons" even if this does not involve any of the means above mentioned, that is, coercion is not a necessary element because a child is considered as a victim of trafficking. ${ }^{13}$

Art. 4 specifies that the scope of application of the Protocol must be limited to transnational crimes in which an organized criminal group is involved. ${ }^{14}$

The so-called Palermo Protocol for the first time sets out a definition of the crime of human trafficking at the international level and deals with the phenomenon in question, not only from the point of view of prevention and repression of the phenomenon but also under the profile of the tools to be provided for the protection of the victims of trafficking. ${ }^{15}$

The articles dedicated to the protection of victims of trafficking are Art. 6, "Assistance to and protection of victims of trafficking in persons", Art. 7, on the "Status of victims of trafficking in persons in receiving States" and Art. 8 dedicated to the "Repatriation of victims of trafficking in persons" which pro-

tegrazione europea, 3, 2011, p. 609 ss.; Giammarinaro, La direttiva 2011/36/UE sulla prevenzione e la repressione della tratta di esseri umani e la protezione delle vittime, in Diritto immigrazione e cittadinanza, 2012, 1, p. 15 ss.

13 Trafficking can be defined as the situation that results from the combination of three elements: the acts carried out by the responsible (the recruitment, transportation, transfer, etc.), the means by which the participation of the victim is obtained and/or his consent is extorted (the use or threat of use of force, fraud, kidnapping, etc.), the end (identified in the various forms of exploitation).

14 Scope of application: "This Protocol shall apply, except as otherwise stated herein, to the prevention, investigation and prosecution of the offences established in accordance with Article 5 of this Protocol, where the offences are transnational in nature and involve an organized criminal group, as well as to the protection of the rights of persons who have been the object of such offences"

15 Rijken, Trafficking in Human Beings for Labour Exploitation: Cooperation in an Integrated Approach, in European Journal of Crime, Criminal Law and Criminal Justice, 2013, 21, p. 9 ss. 
vides a number of safeguards that States must bear in mind in the event of the return of the victims to the State where the victim of trafficking in persons is a national or in which the person had the right of permanent residence.

Specific attention is paid by the aforementioned Protocol to the irrelevance of consent which, although provided, is still and always flawed by virtue of the element of coercion by which the consent is extorted and the irrelevance of the coercive means and not used when the victim is a minor.

Art. 5 provides for a specific obligation for Member States consisting in "establishing as criminal offenses" in their respective internal legislations all conducts falling within the definition of trafficking.

The rules on preventive measures and cooperation are the most important element of this international instrument, and are taken quite faithfully by the Warsaw Convention and the European normative acts on trafficking.

Moreover, the Palermo Protocol underlines the need to design and implement by Member Parties comprehensive policies and programs to combat trafficking in persons and to intervene in a targeted way to promote also in the media the campaigns on the dissemination of information and awareness-raising, as well as education on the issue, also in order to foster cooperation between different States, and between the institutions thereof and non-governmental organizations of various kinds and civil society.

Particular attention is dedicated to the cooperation between the police and border authorities of various countries, the cooperation which presupposes that the men and public officials concerned have received adequate training allowing them an easier identification of typical situations to whom the trafficking is ascribable, and in particular for the checks to be carried out on the travel documents.

The problem of victim's residence is solved by the Protocol with the preference to be given by the Contracting States, to forms of "voluntary" return, while the States have the duty to "take into consideration" the possibility of granting temporary or definitive titles of stay for the victims of trafficking.

It must be recalled that the Protocol on trafficking, supplementing the United Nations Convention of 2000, shares its essential purposes and is itself a tool to contrast criminal organizations involved in trafficking in persons. ${ }^{16}$

In this regard, it seems useful to recall that, in accordance with the UN Convention against organized crime (Art. 3, para. 2), an offense is transna-

16 Art. 2, let. (a) of the United Nations Convention of 2000 specifies that "Organized criminal group" shall mean a structured group of three or more persons, existing for a period of time and acting in concert with the aim of committing one or more serious crimes or offences established in accordance with this Convention, in order to obtain, directly or indirectly, a financial or other material benefit (such as sexual gratification in child pornography traffic). 
tional if: 1) it is committed in more than one State; 2) it is committed in one country but a substantial part of its preparation, planning, direction or control takes place in another State; 3 ) it is committed in one State but it involves an Organized Criminal Group (OCG operating in more than one State; and, 4) it is committed in one country but it has substantial effects in another State.

\section{The Warsaw Convention of 2005}

One of the most important international legal instruments of anti-trafficking having a regional nature is the Council of Europe Convention on Action against Trafficking in Human Beings signed in Warsaw on 16 May 2005 and entered into force on 1 February 2008. ${ }^{17}$

In the Preamble it is specified that trafficking in human beings "constitutes a violation of human rights and an offence to the dignity and the integrity of the human being" and that it "may result in slavery for victims", and it is also noted that the paramount objectives of the Convention must be "respect for victims' rights, protection of victims and action to combat trafficking in human beings". 18

In its introductory part the Convention expressly refers to three European legal instruments: the Council Framework Decision 2002/629/JHA ${ }^{19}$ on combating trafficking in human beings, the Framework Decision 220 of $2001^{20}$ and the Directive 2004/81/EC on the residence permit issued to third-country nationals who are victims of trafficking in human beings or who have been the subject of an action to facilitate illegal immigration, who cooperate with the competent authorities. ${ }^{21}$

The definition of trafficking that is indicated in Art. $4^{22}$ of the Convention essentially reproduces the one of Art. 3 of the Palermo Protocol and is essen-

17 The Italian law authorizing the ratification is the no. 108 of July 2, 2010.

18 Raffaelli, The European Approach to the Protection of Trafficking Victims: the Council of Europe Convention. The EU Directive and the Italian Experience, in German Law Journal, 2009 , 10, p. 205 ss.

19 Council Framework Decision of 19 July 2002 on combating trafficking in human beings (2002/629/JHA).

20 Council Framework Decision of 15 March 2001 on the standing of victims in criminal proceedings (2001/220/JHA).

21 See, in this regard, Scarpa, La tutela dei diritti delle vittime di tratta degli esseri umani ed il sistema premiale previsto dalla direttiva comunitaria 2004/81/CE, in Diritto, immigrazione e cittadinanza, 2005, p. 45 ss.

22 For the purposes of this Convention: a "Trafficking in human beings" shall mean the recruitment, transportation, transfer, harbouring or receipt of persons, by means of the threat or use of force or other forms of coercion, of abduction, of fraud, of deception, of the abuse of power or of a position of vulnerability or of the giving or receiving of pay-

[86] NBP • Žurnal za kriminalistiku i pravo 
tially based on the element of coercion and on the absence of consent of the victim or of a (possible) consensus, however flawed if paid after having suffered coercion, deception, fraud, or abuse of power. Even the Council of Europe Convention does not give any importance to the possible consent given by a minor (even in the absence of coercion and, therefore, of "not extorted" consensus).

Unlike the provisions of the Palermo Protocol (Art. 4), the principles and actions against the trafficking of persons are considered and implemented independently of the internationalist or purely internal profile trafficking, regardless of the existence of links with organized crime (transnational or not), both if the ultimate goal is the sexual exploitation and other (illicit) forms of it. ${ }^{23}$

Moreover, the Warsaw Convention seems more attentive to preventive actions than the Palermo Protocol and it contains the rules aimed at implementing the information/awareness of civil society and at training the staff, while the new types of sanctions and repressive measures, as well as other forms of initiatives to strike the demand for people demonstrate the attention paid by the international legislator to the phenomenon of trafficking in human beings.

In fact, the Convention requires the signatory States to implement a series of measures to prevent the crime of trafficking and to protect the victims, ranging from the protection of privacy, the psychological, medical and social counselling, to the admission to legal aid and the guarantee of compensation by the offenders, even the establishment of a fund for the compensation of victims.

Nevertheless, the characteristic element of the Warsaw Convention is to be found in the "adoption of a perspective particularly careful to the protection of human rights, in consideration of the victims" and, under this specific profile, it states that each Contracting Party provides for, in national legislation

ments or benefits to achieve the consent of a person having control over another person, for the purpose of exploitation. Exploitation shall include, at a minimum, the exploitation of the prostitution of others or other forms of sexual exploitation, forced labour or services, slavery or practices similar to slavery, servitude or the removal of organs; $b$ The consent of a victim of "trafficking in human beings" to the intended exploitation set forth in subparagraph (a) of this article shall be irrelevant where any of the means set forth in subparagraph (a) have been used; c The recruitment, transportation, transfer, harbouring or receipt of a child for the purpose of exploitation shall be considered "trafficking in human beings" even if this does not involve any of the means set forth in subparagraph (a) of this article; $d$ "Child" shall mean any person under eighteen years of age; e"Victim" shall mean any natural person who is subject to trafficking in human beings as defined in this article. 23 The Convention, being based on a non-discriminatory approach (Art. 3) and recognizing trafficking as a violation of human rights and an offense to the dignity and integrity of human beings, applies to all forms of trafficking in human beings, both at national and transnational level, related or not to organized crime. Art. 2: “This Convention shall apply to all forms of trafficking in human beings, whether national or transnational, whether or not connected with organised crime". 
(Art. 13), a recovery and reflection period of at least 30 days when there are reasonable grounds to believe that the person is a victim; during this period it will not be possible to enforce any expulsion order against this person. A renewable residence permit is granted to the victims.

While in the Palermo Protocol the protection of victims and their rights is an instrumental connotation for the prosecution of criminal offenses and the duties of care relate to an area of liberty for the States, the support and assistance of the victims of trafficking in the Warsaw Convention should be guaranteed beyond the collaboration of trafficked persons to investigations.

As well as the Palermo Protocol, the 2005 Warsaw Convention also imposes the States Parties to adopt "such legislative and other measures as may be necessary to establish as criminal offences the conduct contained in Article 4 of this Convention, when committed intentionally" (Art. 18).

The Council of Europe Convention on Action against Trafficking in Human Beings (the Warsaw Convention of 2005) aims at establishing an effective common system of prevention and combating trafficking and, in this regard, a specific monitoring mechanism is activated. This mechanism establishes an expert group (Art. 36) on combating trafficking in human beings, called GRE$\mathrm{TA}$, responsible for monitoring the implementation of the Convention.

\section{Conclusion}

Besides the mentioned acts in this area there are many other relating acts. International legal acts which contain the provisions relevant to the work of defining as criminal the human trafficking and smuggling of migrants are: the United Nations Universal Declaration of Human Rights (1948); the Convention on the Prevention of Trafficking and Exploitation of Prostitution of Others (1949); the Convention for the protection of human rights and fundamental freedoms (1950); the International Covenant on Civil and Political Rights (1966); the Convention on the Elimination of All Forms of Discrimination of Women (1977); General recommendations of the Committee for the elimination of discrimination against women No. 19 (1992); the Beijing Platform for Action IV World Conference on Women (1995); the Hague Ministerial Declaration on European guidelines for effective measures to combat trafficking in women for the purpose of sexual exploitation; the Protocol to Prevent, Suppress and Punish Trafficking of Persons, especially Women and Children, supplementing the United Nations Convention against transnational organized crime (2000); the Protocol against the Smuggling of Migrants by Land, Sea and Air, supplementing the United Nations Convention against Transnational 
Organized Crime (2000); Council of Europe Recommendation 1325 on trafficking in women and forced prostitution in the Council of Europe member states; Recommendation of the Committee of Ministers No. R (2000) on action against trafficking in human beings for the purpose of sexual exploitation; the Proposal for a framework decision of the Commission of the European Union on combating trafficking in human beings, no. 201/0024 (2001). - Regulation of the United Nations concerning the protection of human rights of foreign migrants: ILO Convention on forced or compulsory labor and the prevention of forced labor (1930); The Universal Declaration of Human Rights (1948); the Convention on the equality of men and women workers and equal value of their work (1951); the Convention Relating to the Status of Refugees (1951); the Convention Concerning Discrimination in Respect of Employment and Occupation (1958); the Convention on the Abolition of Forced Labor (1959); the International Covenant on Civil and Political Rights (1966) and Optional Protocol; the International Covenant on Economic, Social and Cultural Rights (1966); the Convention against Torture and Other Cruel and Inhuman or Degrading Treatment (1984); Declaration of Fundamental Rights of Victims of Crime and Victims of Abuse of Power (1985); the Convention on the Rights of the Child (1989); the International Convention on the Protection of the Rights of All Migrant Workers and Members of Their Families (1990); the Convention on the Elimination of the Worst Forms of Child Labor (1996); Model strategies and practical measures to eliminate violence against women in the field of crime prevention and justice (1988); the UN General Assembly Resolution: "Further actions and initiatives to implement the Beijing Platform for Action" (2000); the United Nations Convention against Transnational Organized Crime (2000). - Regulation of the United Nations concerning the protection of human rights of victims of trafficking and smuggled migrants: the International agreement regarding illegal migration and trafficking for effective protection of the criminal trade known as the white slave trade (1904); the International Convention for the Suppression of Trafficking in Women and Children (1921); the Slavery Convention (1926) to the Protocol (1953); the Convention on the Elimination of All Forms of Practice Similar to Slavery (1926); the International Convention for the Suppression of Trafficking in Adult Women (1933); the Universal Declaration of Human Rights (1948); the International Convention for the Suppression of Trafficking in Human Beings (1949); the Convention for the Suppression of the Traffic in Persons and the Exploitation and Prostitution of Others (1950); the Supplementary Convention on the Abolition of Slavery, the Slave Trade, and Institutions and Practices Similar to Slavery Final Act (1956); the International Covenant on Civil and Political Rights (1966) and the Optional Protocol; the International Covenant on Economic, Social and Cultural Rights (1966); the Convention on the Elimination of All Forms of Discrimination against Women - CEDAW (1979); 
Code of Conduct for Law Enforcement Officials (1979); the Convention against Torture and Other Cruel, Inhuman or Degrading Treatment or Punishment (1984); The United Nations Convention on the Rights of the Child (1989); The Declaration on the Elimination of Violence against Women DEVAW (1993); the Beijing Platform for Action of IV World Conference on Women (1995); the Hague Ministerial Declaration on European guidelines for effective measures in combating trafficking in women for the purpose of sexual exploitation; the Protocol to Prevent, Suppress and Punish Trafficking in Human Beings, Especially Women and Children, which supplements the Convention of the United Nations against Transnational Organized Crime (2000); the Protocol against the Smuggling of Migrants by Land, Sea and Air, supplementing the United Nations Convention against Transnational Organized Crime (2000); Rule No. 2001/4 on the Prohibition of Trafficking in Persons in Kosovo (2001); the Optional Protocol on the Sale of Children, Child Prostitution and Child Pornography, the Convention on the Rights of the Child (2002); The Optional Protocol on the Involvement of Children in Armed Conflict, the Convention on the Rights of the Child (2002); Recommendation of Principles and Guidelines on Human Rights and Human Trafficking (2002). - International regulations and recommendations of the Council of Europe (SOE): the Convention on the Protection of Human Rights and Fundamental Freedoms (1950); the European Convention on Extradition (1957); the European Convention on Co-operation in Criminal Matters (1959); the European Social Charter (1966); the Convention on the Compensation of Victims of Violence (1983); Recommendation on the standing of victims in criminal law and criminal procedure (1985); Recommendation on assistance to victims and prevention of victimization (1987); Recommendation on crime policy in Europe (1996); Recommendation that relates to the position of witnesses in relation to the defendant's right of the defence (1997); Recommendation on measures against the organizers of trafficking (1997); Action plan to combat violence against women (1997); Recommendations on action against trafficking in human beings for sexual exploitation (2000); Recommendation on sexual exploitation, pornography and prostitution and trafficking in children and young adults; Recommendations Rec (2001) 16 on the protection of children from sexual exploitation; the European Code of Police Ethics (2001); Proclamation of the Council of Europe Convention on Trafficking in Women (2002); the Council of Europe Convention on Action against Trafficking in Human Beings (2005). - The European Union documents: the so-called Amsterdam Treaty (1999); the Charter of Fundamental Rights (2000); Resolution on the exploitation of prostitutes and trafficking in human beings (1989); Resolution on trade in women (1993); Resolution on trafficking in human beings (1996); Framework Decision Commission Ministerial Council and the European Parliament on trade in women, particularly for the purpose of sexual exploitation 
(1996); the Convention on Extradition between Member States (1996); Resolution on trafficking in women and the corresponding Framework Decision of the Commission on trade in women, especially with the aim of sexual exploitation (1997); the Action Plan for the Prevention of Trafficking and Sexual Exploitation of Children (1997); The Ministerial Declaration on European guidelines for effective measures to prevent and combat trafficking in women for the purpose of sexual exploitation (1997); the Framework Decision of Ministerial Council and the European Parliament with a proposal for further action against trafficking in women (1998); Resolution on Trafficking in Women (2000); the Decision on combating child pornography on the Internet (2000); the Framework Decision of the European Union on the standing of victims in criminal proceedings (2001); the Framework Decision of the EU Council on combating trafficking in human beings (2002); the Framework Decision on combating the sexual exploitation of children and child pornography (2003) and others. - The documents of the Organization for Security and Cooperation: the document with the Moscow Conference on the Human Dimension of the OSCE (1991); the Istanbul Charter for European Security (1999); the Saint-Petersburg declaration of the Parliamentary Assembly of the OSCE on trafficking in women and children (1999); the Declaration of the OSCE Parliamentary Assembly in Bucharest (2000); the decision of the Ministerial Council on strengthening effortlessly OSCE to combat trafficking in human beings (2000); the Porto Declaration on human trafficking (2002). Illegal migration and trafficking in human beings - Documents of the Stability Pact for South Eastern Europe: the Ministerial Declaration Stability Pact for South-eastern Europe Convention on Action against Trafficking in Human Beings (2000).

But this short and not exhaustive examination ${ }^{24}$ of certain rules of the main regulatory instruments of anti-trafficking allows to conclude that, despite international conventions on trafficking in human beings provide a plurality of obligations for the States Parties - the obligations intended to ensure effective penal sanctions for traffickers, effective border controls, information aimed at the individuals with greater risk of recruiting and the appropriate training of the Police - the phenomenon continues to spread. In fact, the European Commissioner for Migration, Home Affairs and Citizenship, on the occasion of the presentation of the first Commission report on the progress made in combating trafficking in human beings, ${ }^{25}$ has stated that "it is unacceptable and in-

24 For reasons of space any consideration is made of the anti-trafficking European Union's normative acts.

25 Report of the Commission to the European Parliament and the Council. Report 2016 on the progress made in the fight against trafficking in human beings in accordance with Article 20 of the Directive 2011/36 / EU on preventing and combating trafficking in human beings and protecting victims, Brussels, May 19, 2016, сом(2016) 267 final. 
excusable, morally and legally, that in the European Union of the twenty-first century human beings are bought, sold and exploited as commodities ..."

\section{References}

1. Amalfitano, C; Unione europea e tutela delle vittime della tratta di esseri umani, in G. Caggiano (a cura di), I percorsi giuridici per l'integrazione. Migranti e titolari di protezione internazionale tra diritto dell'Unione e ordinamento italiano, Torino, 2014, p. 755.

2. Carella, A; La tratta degli esseri umani, in AA. Vv., L'immigrazione e la mobilità delle persone nel diritto dell'Unione europea, Milano, 2012, p. 207 ss;

3. Gabrielli, A; La Direttiva sulla tratta di esseri umani tra cooperazione giudiziaria penale, contrasto dell'immigrazione illegale e tutela dei diritti, in Studi sull'integrazione europea, 3, 2011, p. 609 ss.; Giammarinaro, M. G. La direttiva 2011/36/UE sulla prevenzione e la repressione della tratta di esseri umani e la protezione delle vittime, in Diritto immigrazione e cittadinanza, 2012, 1, p. 15 ss.

4. Forlati, S. (a cura di), La lotta alla tratta di esseri umani fra dimensione internazionale e ordinamento interno, Napoli, 2013;

5. Gallagher, A. T; The international law of human trafficking, Cambridge University Press, New York, 2010.

6. Middlburg, A; Rijken, C; The EU Legal Framework on Combating Trafficking in Human Beings for Labour Exploitation, in C. Rijken (ed.), Combating Trafficking in Human Beings for Exploitation, Nijmegen, The Netherlands, Wolf Legal Publishers WLP, 2011.

7. Nascimbene, B. Di Pascale, A; Riflessioni sul contrasto al traffico di persone nel diritto internazionale, comunitario e nazionale, in G. PALMisano (a cura di), Il contrasto al traffico di migranti nel diritto internazionale, comunitario e interno, Milano, 2008, p. 27 ss.

8. Rijken, R; Trafficking in Human Beings for Labour Exploitation: Cooperation in an Integrated Approach, in European Journal of Crime, Criminal Law and Criminal Justice, 2013, 21, p. 9 ss.

9. Obokata, T; EU Council Framework Decision on Combating Trafficking in Human Beings: a Critical Appraisal, in Common Market Law Review, 2003, p. 917 ss.

10. Rijken, C; The external dimension of EU policy on trafficking in human beings, in Cremona m., Monar J. E Poli S. (eds.), the external dimension 
of the European Union's area of freedom, security and justice, p.i.e. Peter Lang, 2011, P. 212.

11. Raffaelli, R; The European Approach to the Protection of Trafficking Victims: the Council of Europe Convention. The EU Directive and the Italian Experience, in German Law Journal, 2009, 10, p. 205 ss.

12. Scarpa, S; La tutela dei diritti delle vittime di tratta degli esseri umani ed il sistema premiale previsto dalla direttiva comunitaria 2004/81/CE, in Diritto, immigrazione e cittadinanza, 2005, p. 45 ss.

13. Report of the Commission to the European Parliament and the Council. Report 2016 on the progress made in the fight against trafficking in human beings in accordance with Article 20 of the Directive 2011/36 / EU on preventing and combating trafficking in human beings and protecting victims, Brussels, May 19, 2016, $\operatorname{CoM(2016)~} 267$ final.

14. Council Framework Decision of 19 July 2002 on combating trafficking in human beings (2002/629/JHA).

15. Council Framework Decision of 15 March 2001 on the standing of victims in criminal proceedings (2001/220/JHA).

16. Additional Protocol to the United Nations Convention against Transnational Organized Crime to Prevent, Suppress and Punish Trafficking in Persons, especially Women and Children. Adopted by the General Assembly Resolution A/RES/55/25 of 15 November 2000. Entered into force on December 25, 2003. The Italian law authorizing the ratification is the no. 146 of March 16, 2006 (Official Journal no. 85 of April 11, 2006). Date of deposit of the instrument of ratification: August 2, 2006. Entry into force in Italy: September 1, 2006. 


\title{
EVROPSKI I MEĐUNARODNI STANDARDI U OBLASTI TRGOVINE LJUDIMA
}

\author{
Ana Lucia Valvo \\ Univerzitet Kore, Ena, Italija
}

Sažetak: Autorka se u radu bavi veoma aktuelnom problematikom trgovine ljudima, sa aspekta pravnih akata i normi koje regulišu ovu oblast na globalnom nivou. Rad predstavlja presek stanja u oblasti i pokušaj prikazivanja razvijenih pravnih standarda kroz analizu postojećih Konvencija, Statuta i drugih akata određenih organizacija. U analizi koju sprovodi, autorka se najviše fokusira na prikaz Varšavske Konvencije iz 2005, ukazujući na prednosti i mane tretiranja ove materije. Ovaj rad predstavlja pokušaj da se prikažu standardi koji su bez sumnje razvijeni posebno u ovoj oblasti u kojoj postoji interes velikog broja značajnih evropskih zemalja, ali i interesi malih i nerazvijenih zemalja iz kojih se ljudi krijumčare. Autorka ukazuje i na probleme iregularnih migracija i delom načine regulisanja ove oblasti u svetlu prikazivanja standarda i u ovoj oblasti, ali se celokupan rad svodi na trasiranje standarda u oblasti trgovine ljudima. 